\title{
Aspects related to the outcomes of the treatment, in international borders, of cases of tuberculosis as associated to comorbidities
}

\author{
Aspectos relacionados ao desfecho de tratamento dos casos de tuberculose \\ associadas à comorbidades em situação de fronteira internacional \\ Aspectos relacionados con el resultado de tratamiento de los casos de tuberculosis \\ asociados a comorbilidades en situación de frontera internacional
}

How to cite this article: Souza DCS, Oliveira KS, Andrade RLP, Scatena LM, Silva-Sobrinho RA. Aspects related to the outcomes of the treatment, in international borders, of cases of tuberculosis as associated to comorbidities. Rev Gaúcha Enferm. 2019:40:e20190050. doi: https://doi.org/10.1590/19831447.2019.20190050 a Universidade Estadual do Oeste do Paraná (Unioeste), Programa de Pós-Graduação em Saúde Pública em Região de Fronteira. Foz do Iguaçu, Paraná, Brasil.

- Universidade de São Paulo (USP), Escola de Enfermagem de Ribeirão Preto. Ribeirão Preto, São Paulo, Brasil.

Universidade Federal do Triângulo Mineiro (UFTM) Instituto de Ciências da Saúde, Departamento de Saúde Coletiva. Uberaba, Minas Gerais, Brasil.

\section{Débora Christina Santos Souza ${ }^{a}$ Keurilene Sutil de Oliveira ${ }^{a}$ Rubia Laine de Paula Andrade ${ }^{b}$ Lucia Marina Scatenac Reinaldo Antonio Silva-Sobrinho ${ }^{a}$}

\section{ABSTRACT}

Objective: analyzing the aspects associated with case outcomes and the international border situation when it comes to patients with tuberculosis (TB) associated with comorbidities.

Method: exploratory descriptive epidemiological study, analyzing all new cases of TB with comorbidities reported in 2013 on SISNAN in the cities at the border of the state of Paraná and Paraguay. The variables used were: sociodemographic, clinical and operational. To analyze the data, descriptive analysis and the chi-square test were applied.

Results: 227 cases of tuberculosis associated with comorbidities were reported and 70.9\% were from cities bordering Paraguay. Alcoholism (22.0\%) and AIDS (13.7\%) were the most common comorbidities. The chi-square test presented a statistical association of border cities with negative outcomes and not performing directly observed treatments.

Conclusion: Through the study, it was possible to find that the location of border cities can be determinant for a negative outcome. Keywords: Tuberculosis. Comorbidity. Treatment outcome. Border health.

\section{RESUMO}

Objetivo: Analisar os aspectos associados ao desfecho do caso e à situação de fronteira internacional entre doentes de tuberculose com comorbidades.

Método: Estudo epidemiológico, descritivo exploratório, analisando todos os casos novos de Tuberculose com comorbidades notificados no ano 2013 no Sistema de Informação de Agravos de Notificação em municípios de fronteira do estado do Paraná com o Paraguai. As variáveis utilizadas foram: sociodemográficas, clínicas e operacionais. Para analisar os dados aplicou-se análise descritiva e 0 teste qui-quadrado

Resultados: Dos 227 casos de tuberculose com comorbidades, 70,9\% eram de municípios que faziam fronteira com o Paraguai. 0 alcoolismo (22,0\%) e a aids (13,7\%) foram as comorbidades mais frequentes. 0 teste que qui-quadrado apresentou associação estatística para os municípios de fronteira com desfecho desfavorável e que não realizam o tratamento diretamente observado.

Conclusão: Pelo estudo, é possível identificar que a localização dos municípios de fronteira pode ser determinante para um desempenho desfavorável.

Palavras-chave: Tuberculose. Comorbidade. Resultado do tratamento. Saúde na fronteira.

\section{RESUMEN}

Objetivo: Analizar los aspectos asociados al cierre del caso y a la situación de frontera internacional entre enfermos de tuberculosis con comorbilidad.

Método: Estudios epidemiológico, descriptivo exploratorio, analizando todos los casos nuevos de TB con comorbilidad notificados en el año 2013 en SISNAN en municipio de frontera del Estado de Paraná con Paraguay. Las variables utilizadas fueron: sociodermográficas, clínicas y operacionales. Para analizar los datos se aplicó análisis descriptiva y el test qui-cuadrado.

Resultados: De los 227 casos de tuberculosis con comorbilidades, el 70,9\% eran de municipios que hacían frontera con Paraguay. El alcoholismo (22,0\%) y el sida (13,7\%) fueron las comorbilidades más frecuentes. La prueba que qui-cuadrado presentó asociación estadística para los municipios de frontera con desenlace desfavorable y que no realizan el tratamiento directamente observado.

Conclusión: Por el estudio, es posible identificar que la localización de los municipios de frontera puede ser determinante para un desempeño desfavorable

Palabras Claves: Tuberculosis. Comorbilidad. Resultado del tratamiento. Salud fronteriza. 


\section{口INTRODUCTION}

Tuberculosis (TB) is still a serious public health problem throughout the world, since, despite having a cure, the World Health Organization (WHO) pointed out in 2018 that it is the infectious disease with the highest death toll in the world, even above AIDS. Estimates indicated that 10.4 million people were contaminated by the TB bacillus in 2016, among whom 1.3 million did not survive ${ }^{(1)}$.

Brazil has the highest incidence coefficient of the disease in the Americas and is the 20th country with the most cases in the world, being one of the countries in which actions to manage the disease should be given priority. Regarding the TB/HIV co-infection, the country is in the 19th position in the list of 30 priority countries. These recommendations regarding the countries in which TB control should be a priority is determined by the $\mathrm{WHO}^{(1)}$.

It stands out that regions in international borders have a higher incidence of TB than others ${ }^{(2)}$, with worse results regarding the outcome of the treatment. Factors related to these local features are: inequality and social exclusion, poor living conditions, migration, population aging, and opportunistic diseases ${ }^{(3)}$. These negative results may also be generated by the movements of the populations who live in these areas, in one direction or the other, seeking better healthcare services. That may prevent the problem from being detected in the country where the person lives and from which the disease originated ${ }^{(4)}$.

A study carried out in a city at the country's border found that diabetes mellitus (DM), alcoholism, mental disorders, and HIV/AIDS are the most frequent comorbidities in TB cases $^{(5)}$. Therefore, it is important to highlight how complex it is to offer healthcare to people with multiple chronic conditions, since the occurrence and advance of one condition influences in the occurrence and advance of the others ${ }^{(6)}$.

Thus, it is relevant to study cases in which TB presents itself associated with comorbidities in regions near borders, as to propose intervention strategies to qualify the healthcare that can be offered to these individuals, thus leading to better results in their treatment. Therefore, this study aims to analyze the aspects associated to the outcome of cases and to the situation of international borders as it relates to patients with TB associated with comorbidities.

\section{口 METHOD}

This is an epidemiological, descriptive, and exploratory study, including 22 cities from the state of Paraná, all of which are at the border between Brazil and Paraguai: Foz do Iguaçu; Santa Terezinha de Itaipu; São Miguel do Iguaçu; Itaipulândia; Missal; Santa Helena; Entre Rios do Oeste; Marechal Cândido Rondon; Guaíra; Pato Bragado; and Mercedes. The cities that were not at the border with Paraguai (Colombo, Loanda, Itaperuçu, Alto Piquiri, Pérola, Cambará, Cruzeiro do Iguaçu, Prudentópolis, Matinhos, Saudade do Iguaçu, Santa do Itararé) were intentionally selected since their population was equivalent to that of the ones at the border. In the state of Paraná, 2,559 new TB cases were registered in 2013, with an index of cure of $75 \%$, below the $85 \%$ stipulated by the WHO.

The population of the study was made up by all new cases of TB associated with comorbidities (AIDS, alcoholism, DM, mental disorders, others), notified in the year 2013 who were treated in the cities mentioned above.

The data to carry out the study were obtained from the System of Health Problem Information Notification (SINAN), obtained with the State Health Secretariat of Paraná, in 2016. The variables of interest were separated into three categories: Sociodemographic variables - age, sex (male, female), race/color (white, brown, others), from a city on the border (yes, no); Clinical variables - clinical form of TB (pulmonary, extrapulmonary, pulmonary + extrapulmonary), catarrh baciloscopy in the diagnostic (positive, negative, not performed), comorbidities (alcoholism, AIDS, diabetes mellitus, mental disorders); Operational variables - anti-HIV test (positive, negative, not performed), directly observed treatment (DOT) (yes, no); outcome of the treatment (cured, not cured). When the discharge of the patient was not due to a cure in the end of the treatment, the result was registered as "negative outcome".

Data was analyzed using frequency distribution, mean and standard deviation. To test the association between the outcome (cure or no cure) and the location of the cities (at a border or not at a border) with the sociodemographic, clinical, and operational variables, the chi-square test was used. The statistical significance level adopted for all analyses was 5\%. The software Statistica 12.0 was used to analyze the variables.

This study was approved by the Research Ethics Committee (CEP) of the Universidade Estadual do Oeste do Paraná, under protocol 1.697.490.

\section{RESULTS}

The investigation found 227 records that were in accordance to the inclusion criteria, with 129 patients from Foz do Iguaçu, 35 in Colombo, 25 in Matinhos, 18 in Guaíra, eight in Marechal Candido Rondon, three in Cambará, two in Santa Terezinha de Itaipu, two in Santana, two in 
São Miguel do Iguaçu and one per city in Loanda, Mercedes and Santa Helena. Ten cities had no case within the stablished parameters.

The mean age of participants in the study was 38.4 ( \pm 15.6$)$. Table 1 shows that most notified cases involved males (66.9\%), white persons (63.9\%), from the group of cities who are at the border with Paraguay (70.9\%).
Regarding the clinical variables, most cases involved pulmonary TB (89.4\%) with positive catarrh baciloscopy (61.7\%). Alcoholism (22.0\%) and AIDS (13.7\%) were the most common comorbidities, among others (53.7\%) that could not be identified. Regarding operational variables, $10.1 \%$ of participants did not undergo anti-HIV tests, $89.9 \%$ underwent the DOT and $71.8 \%$ found a cure (Table 1).

Table 1 - Distribution of sociodemographic, clinical, and operational variables of the cases of tuberculosis with comorbidities in cities in Paraná, 2013

\begin{tabular}{|c|c|c|c|}
\hline \multicolumn{2}{|c|}{ Sociodemographic, clinical, and operational variables } & $\mathbf{n}$ & (\%) \\
\hline \multirow{2}{*}{ Sex } & Male & 152 & $(66.9)$ \\
\hline & Female & 75 & (33.1) \\
\hline \multirow{3}{*}{ Race/color } & White & 145 & (63.9) \\
\hline & Brown & 57 & $(25.1)$ \\
\hline & Other & 25 & $(11.0)$ \\
\hline \multirow{2}{*}{ City at the border } & Yes & 161 & $(70.9)$ \\
\hline & No & 66 & $(29.1)$ \\
\hline \multirow{3}{*}{ Clinical form of TB } & Pulmonary & 203 & $(89.4)$ \\
\hline & Extrapulmonary & 19 & $(8.4)$ \\
\hline & Pulmonary + extrapulmonary & 5 & $(2.2)$ \\
\hline \multirow{3}{*}{ Catarrh bacilloscopy at the diagnostic } & Positive & 140 & $(61.7)$ \\
\hline & Negative & 55 & $(24.2)$ \\
\hline & Not performed & 32 & $(14.1)$ \\
\hline \multirow{5}{*}{ Comorbidities } & Alcoholism & 50 & $(22.0)$ \\
\hline & AIDS & 31 & $(13.7)$ \\
\hline & Diabetes mellitus & 17 & $(7.5)$ \\
\hline & Mental disorder & 7 & $(3.1)$ \\
\hline & Other* & 122 & $(53.7)$ \\
\hline \multirow{3}{*}{ Anti-HIV test } & Positive & 31 & $(13.7)$ \\
\hline & Negative & 173 & $(76.2)$ \\
\hline & Not performed & 23 & $(10.1)$ \\
\hline \multirow{2}{*}{ Directly observed treatment } & Yes & 204 & $(89.0)$ \\
\hline & No & 23 & $(10.1)$ \\
\hline \multirow{6}{*}{ Treatment outcome } & Cured & 163 & $(71.8)$ \\
\hline & Abandonment & 39 & $(17.2)$ \\
\hline & Death by TB & 10 & $(4.4)$ \\
\hline & Death from other causes & 9 & $(4.0)$ \\
\hline & Resistante TB & 5 & $(2.2)$ \\
\hline & Change in the scheme of treatment & 1 & $(0.4)$ \\
\hline
\end{tabular}

Source: SINAN, 2013.

*Space to be filled with a description and information on other diseases or health conditions not listed in the options available (Alcoholism, AIDS, Diabetes, and Mental Disorders). In the option "others", eight records were left unfilled/ ignored and the others were highly varied, being impossible to categorize. 
Through table 2, it was possible to find a statistically significant association $(p<0.05)$ between a negative outcome and the cities that are at the border with Paraguai.
Table 3 shows a statistically significant association between undergoing DOTs and the cities that are not located at the border.

Table 2 - Distribution of the outcomes of the treatment of individuals with tuberculosis and comorbidities, according to sociodemographic, clinical, and operational variables in cities from Paraná, 2013

\begin{tabular}{|c|c|c|c|c|}
\hline \multirow{2}{*}{\multicolumn{2}{|c|}{$\begin{array}{l}\text { Sociodemographic, clinical, } \\
\text { and operational variables }\end{array}$}} & \multicolumn{2}{|c|}{ Outcomes } & \multirow{2}{*}{ Test Chi-square $p$} \\
\hline & & Cured n (\%) & Not-cured n (\%) & \\
\hline \multirow{2}{*}{ Sex } & Male & $108(66.3)$ & $44(68.7)$ & \multirow{2}{*}{0.7194} \\
\hline & Female & $55(37.7)$ & $20(31.3)$ & \\
\hline \multirow{3}{*}{ Race/color } & White & $105(64.4)$ & $40(62.5)$ & \multirow{3}{*}{0.9504} \\
\hline & Brown & $18(11.0)$ & $7(10.9)$ & \\
\hline & Other & $40(24.6)$ & $17(26.6)$ & \\
\hline \multirow{2}{*}{$\begin{array}{l}\text { Cities at the border } \\
\text { with Paraguay }\end{array}$} & Yes & $105(64.4)$ & $56(87.5)$ & \multirow{2}{*}{$0.0006^{*}$} \\
\hline & No & $58(35.6)$ & $8(12.5)$ & \\
\hline \multirow{3}{*}{ Clinical form of TB } & Pulmonary & $145(89.0)$ & $58(90.6)$ & \multirow{3}{*}{0.6579} \\
\hline & Extrapulmonary & $15(9.2)$ & $4(6.3)$ & \\
\hline & $\begin{array}{l}\text { Pulmonary } \\
+ \text { extrapulmonary }\end{array}$ & $3(1.8)$ & $2(3.1)$ & \\
\hline \multirow{3}{*}{$\begin{array}{l}\text { Catarrh bacilloscopy at } \\
\text { the diagnostic }\end{array}$} & Positive & $98(60.1)$ & $42(65.6)$ & \multirow{3}{*}{0.2654} \\
\hline & Negative & $44(27.0)$ & $11(17.2)$ & \\
\hline & Not performed & $21(12.9)$ & $11(17.2)$ & \\
\hline \multirow{2}{*}{ Alcoholism** } & Yes & $31(19.3)$ & 19 (29.7) & \multirow{2}{*}{0.0895} \\
\hline & No & $130(80.7)$ & $45(70.3)$ & \\
\hline \multirow{2}{*}{ AIDS** } & Yes & 18 (11.4) & $13(20.6)$ & \multirow{2}{*}{0.0741} \\
\hline & No & $140(88.6)$ & $50(79.4)$ & \\
\hline \multirow{2}{*}{ Diabetes mellitus ** } & Yes & $15(9.4)$ & $2(3.2)$ & \multirow{2}{*}{0.1162} \\
\hline & No & $145(90.6)$ & $61(96.8)$ & \\
\hline \multirow{2}{*}{ Mental disorder** } & Yes & $3(1.9)$ & $4(6.4)$ & \multirow{2}{*}{0.0827} \\
\hline & No & $158(98.1)$ & 59 (93.6) & \\
\hline \multirow{3}{*}{ Anti-HIV test } & Positive & $18(11.1)$ & $13(20.3)$ & \multirow{3}{*}{0.1653} \\
\hline & Negative & $129(79.1)$ & $44(68.8)$ & \\
\hline & Not performed & $16(9.8)$ & 7 (10.9) & \\
\hline \multirow{2}{*}{$\begin{array}{l}\text { Directly } \\
\text { observed treatment }\end{array}$} & Yes & $144(88.3)$ & $60(93.7)$ & \multirow{2}{*}{0.2245} \\
\hline & No & 19 (11.7) & $4(6.3)$ & \\
\hline
\end{tabular}

Source: SINAN, 2013

Note: " $p<0.05$; " Participants whose data was blank/ignored in the SINAN-PR were excluded from the analysis. 
Table 3 - Distribution of individuals with tuberculosis and comorbidities according to the location of the city and according to sociodemographic, clinical, and operational variables, cities of Paraná, 2013

\begin{tabular}{|c|c|c|c|c|}
\hline \multirow{2}{*}{\multicolumn{2}{|c|}{$\begin{array}{l}\text { Sociodemographic, clinical, } \\
\text { and operational variables }\end{array}$}} & \multicolumn{2}{|c|}{ City at the border } & \multirow{2}{*}{ Test Chi-square $p$} \\
\hline & & Yes n (\%) & No n (\%) & \\
\hline \multirow{2}{*}{ Sex } & Male & $111(68.9)$ & $41(62.1)$ & \multirow{2}{*}{0.3209} \\
\hline & Female & $50(31.1)$ & $25(37.9)$ & \\
\hline \multirow{3}{*}{ Race/color } & White & $104(64.6)$ & $41(62.1)$ & \multirow{3}{*}{0,7210} \\
\hline & Brown & $41(25.5)$ & $16(24.3)$ & \\
\hline & Other & $16(9.9)$ & $9(13.6)$ & \\
\hline \multirow{3}{*}{ Clinical form of TB } & Pulmonary & $144(89.4)$ & $59(89.4)$ & \multirow{3}{*}{0.8354} \\
\hline & Extrapulmonary & $14(8.7)$ & $5(7.6)$ & \\
\hline & $\begin{array}{l}\text { Pulmonary } \\
+ \text { extrapulmonary }\end{array}$ & $3(1.9)$ & $2(3.0)$ & \\
\hline \multirow{3}{*}{$\begin{array}{l}\text { Catarrh bacillscopy at } \\
\text { the diagnostic }\end{array}$} & Positive & $97(60.3)$ & $43(65.2)$ & \multirow{3}{*}{0.7684} \\
\hline & Negative & $40(24.8)$ & $15(22.7)$ & \\
\hline & Not performed & $24(14.9)$ & $8(12.1)$ & \\
\hline \multirow{2}{*}{ Alcoholism** } & Yes & $34(21.3)$ & $16(24.6)$ & \multirow{2}{*}{0.5821} \\
\hline & No & $126(78.8)$ & $49(75.4)$ & \\
\hline \multirow{2}{*}{ AIDS } & Yes & $26(16.7)$ & $5(7.7)$ & \multirow{2}{*}{0.0800} \\
\hline & No & $130(83.3)$ & $60(92.3)$ & \\
\hline \multirow{2}{*}{ Diabetes mellitus ** } & Yes & $13(8.2)$ & $4(6.3)$ & \multirow{2}{*}{0.6239} \\
\hline & No & $146(91.8)$ & $60(93.8)$ & \\
\hline \multirow{2}{*}{ Mental disorder** } & Yes & $6(3.8)$ & $1(1.6)$ & \multirow{2}{*}{0.3952} \\
\hline & No & $154(96.3)$ & $63(98.4)$ & \\
\hline \multirow{3}{*}{ Anti-HIV test } & Positive & $26(16.2)$ & $5(7.6)$ & \multirow{3}{*}{0.2317} \\
\hline & Negative & $119(73.9)$ & $54(81.8)$ & \\
\hline & Not performed & $16(9.9)$ & $7(10.6)$ & \\
\hline \multirow{2}{*}{$\begin{array}{l}\text { Directly } \\
\text { observed treatment }\end{array}$} & Yes & $116(72.1)$ & $63(95.5)$ & \multirow{2}{*}{$<0,0001^{*}$} \\
\hline & No & 45 (27.9) & $3(4.5)$ & \\
\hline
\end{tabular}

Source: SINAN, 2013

Note: * $p<0.05$; " Participants whose data was blank/ignored in the SINAN-PR were excluded from the analysis.

\section{DISCUSSION}

The first thing that must be discussed is the high incidence of TB associated with comorbidities in the cities at the border of the country in the state of Paraná, since these cities had a population that was the same size of the other cities in the research. The geopolitical and economic setting (international border), in addition to the cultural one (different ethnicities, habits, languages) and to the different health behaviors (between visitors and residents) increase 
the risk of infection by TB and other diseases, leading to tension and to new challenges for the health systems in cities at borders, requiring more attention to healthcare ${ }^{(4)}$.

The TB incidence rates in Paraguay and in the Districts of Alto Paraná and Canindeyú (territories of the cities that share a border with the Brazilian cities in the state of Paraná) was, respectively, 37, 48.6, and 30.2 cases per 100 thousand people in $2017^{(1)}$. In Brazil, however, the incidence rates in the same period was of 33.5 cases per 100 thousand people. In the state of Paraná, it was 17.2 cases per 100 thousand people ${ }^{(7)}$.

In the dynamics of TB transmission, population interactions are understood as highly important and decisive to manage the disease. Therefore, the high incidence rates of the disease in this international macro-space is under the influence of the intense transit of people.

An example are the cities of Foz do Iguaçu and Guaíra (both in the study), which are contiguous with Paraguaian cities (twin-cities). They are known for their intense commerce, since they are free trade zones, in which salespeople, tourists from different nationalities, and especially, people who live in the cities at the border, are in contact.

Additionally, in the last five years, there has been a floating population of nearly 15 thousand Brazilian studies, who went to border cities to study medicine in Paraguay. These students are influenced by the social and sanitary conditions of these urban conglomerates, also influencing these conditions.

These particularities of cities at the border are elements that make TB management even more complex when it comes to risks of transmission, inequalities in the access to a diagnoses, to a treatment, and especially, in the cure of the disease.

Still, considering the public and universal character of the Brazilian public health system, Paraguayans resort to the health services in the Brazilian border cities, especially in Immediate Care Units (UPA), seeking care for TB (and other conditions). On the other hand, Braziguayans (Brazilians who emigrated to Paraguay), since they have houses or family members in Brazil, still have a valid registry in the Unified Health System (SUS), and resort to the health services in the Brazilian border cities (UPAs, hospitals, labs, and Primary Healthcare - APS).

It stands out that TB management in border regions is difficult to achieve, due to the transit of people in these locations and the fast passage from one side to the other of the border, making it easier for the disease to spread in the area. In addition, efforts are required from both countries who share the border ${ }^{(4)}$, such as: bilateral agreements to finance and offer healthcare (respecting national/ international law, but legally adapted to care for the needs presented by the local context), shared management of health program/systems, co-participative health surveillance services, among others.

In this study, there were 2.0 times more men with TB associated with comorbidities than women, a stronger relation than that found in cities at the border of the Amazon state ${ }^{(8)}$. A highest percentage of TB cases in men is in accordance to the recognized behavior of the disease in many other contexts.

The occurrence of TB was also higher among white individuals, which reflects the fact that the population of Paraná is mostly white (67.6\%), according to statistics from 2016. It should be highlighted that the category "others", which includes black and native Brazilians, seems not to present the same high TB incidence rates others studies in border regions have found ${ }^{(8-9)}$.

The pulmonary variant of TB is the most common, a fact with epidemiological relevance due to the ease of transmission of this variant ${ }^{(9)}$. The same was true for this study, which has shown that catarrh bacilloscopies are important allies of health services to diagnose the variant, since the exam was carried out in $85.9 \%$ of cases and had $61.7 \%$ positive results.

Nearly $10 \%$ of all TB cases in the world can be attributed to alcohol abuse $\mathrm{e}^{(9)}$. This comorbidity, frequently associated to poor life conditions and social marginalization, was the most common in this study. Alcohol abuse predisposes the person to develop TB and worsens their clinical situation by diminishing their immunity, leaving them malnourished and exposed to risk situations ${ }^{(10)}$.

HIV testing in the cities studied was 52\% more common than in the national territory. This result is coherent with the performance of the state of Paraná, which is one of the three states of the federation with the highest percentage of tests performed in 2013. This may be reflected on the real situation of TB/HIV co-infections in these cities, since the positive results for anti-HIV in TB cases (13.7\%) was higher than the results in the country (9.8\%) and in the world (12.0\%) in the same period ${ }^{(10-11)}$. The high incidence of TB/HIV co-infections in the region of the Brazilian south border ${ }^{(12-13)}$ is different from the results found in a study in the state of Mato Grosso do Sul, which identified that being at the border was a protective factor to HIV co-infections ${ }^{(9)}$.

The Pan American Health Organization points out that DM makes a person three times more likely to acquire TB, in accordance to the fact that DM was the third morbidity most commonly associated to TB in this study. Authors also state that, in addition to being a risk factor for TB, DM contributes to bring forth latent cases $^{(13-14)}$. 
Studies ${ }^{(9,14)}$ pointed out that the presence of comorbidities is a predicting factor for the unsuccessful treatment of cases of TB. However, in this study, no comorbidity had a statistically significant association with a negative outcome. This finding is questioned by the authors of this study themselves, since the entire population of the study is made up of individuals with comorbidities, making it impossible to compare the results with individuals with no comorbidities.

The results of this study show that the outcome of the treatment is worse in border regions than in others. This also took place in other studies $s^{(9,15)}$ and can be explained by the location of the cities ${ }^{(16)}$ and the difficulties in implementing the DOT in these regions, due to the transit of individuals who leave their countries and come to Brazil seeking "free" healthcare ${ }^{(12,16)}$, and later are not found to follow up on their treatment because they offered imprecise addresses or addresses from the neighboring country.

These situations have become more common since, in recent years, people from South and Central America have been migrating to Brazil due to humanitarian reasons ${ }^{(17)}$. Regarding this issue, different aspects of the health/disease interaction increase the vulnerability of migrants to TB infection during transit and settling down in their destiny, usually settlements for migrants, mostly in border regions, which usually have low capabilities regarding social and health assistance, meaning not only that migrants are a population susceptible to TB, but also making it more difficult to manage the disease ${ }^{(18)}$.

In this study, the free transit of people between Paraguay and Brazil influences TB management in Brazil. It is very common for people in these cities to live in one country and work in the other. In these situations, it becomes easier to contact people who have TB and are not being treated, since there are family and friendship bonds in both sides of the border.

Other difficulties in confronting TB in Brazilian cities at the border with Paraguay is continuing the treatment, evaluating domiciliary contacts, and carrying out other TB-related surveillance activities with Braziguayans and Paraguayans who resort to Brazilian health services, but do not go back to receive treatment after receiving a diagnostic, making it difficult to reach the goal established by the "Strategy to End TB"(1).

These aspects become evident when the rates of cases of TB associated with comorbidities in cities at the border with Paraguay (70.9\%) were compared to that of cities that are not at the border. The study also found a statistical association between all border cities with negative outcomes and not performing the DOT. Another study should also be highlighted, which indicated that people who live in the border are more often affected by pulmonary TB and have a higher chance of abandoning the treatment and dying due to the disease ${ }^{(8)}$.

In border regions, health is a strategic element for integrating border societies and citizens. Therefore, studies have been highlighting the importance of implementing strategies that can bring together separate health systems ${ }^{(19)}$, offering healthcare actions targeted at the first level of healthcare.

The Primary Healthcare System (APS) is the main gateway into the health service, and as such, it needs to be organized considering the premises of "health surveillance". It is structured as the center of communication of the Healthcare Network, and organized to integrate clinical and epidemiological knowledge, not only in the challenges to be answered by the healthcare system of a city. Therefore, this study suggests the working process called "integration team"(20).

As a result, TB management shows itself to be healthcare, sectoral management, favoring the autonomy, as well as the social and cultural heterogeneity of individuals and populations, in accordance to principles of integrality in health.

From these premises, this study argues that the APS of cities in international borders should organize clinical and management protocols to investigate Respiratory Symptoms, monitor suspect cases, diagnose early, and treat cases regardless of the nationality or country of residence of a person, since social vulnerability and risk factors are shared, due to the interactions among people who live in border regions.

Still, under the scope of health surveillance, it becomes necessary to create bilateral administrative agreements between border cities, aiming to integrate health services that work separately, a task known to be difficult. However, this type of integration was already shown to be possible in the offering of APS-related healthcare actions ${ }^{(8)}$.

Not only this integration is necessary, but it is also essential to invest in the diminution of social inequalities and of the negative impact of TB in the economic growth and social development of these countries ${ }^{(19)}$.

\section{CONCLUSION}

Through this study, it was possible to find that the profile of individuals with TB associated with other morbidities in the cities analyzed in the state of Paraná was similar to the epidemiological profile of TB in other locations. The fact that these were cities at international borders was 
associated to negative outcomes of TB cases and low DOT implementation, suggesting that healthcare to TB patients in these places should be treated with attention.

As limiting factors of this study, stand out the impossibility of inferring causes and effects and, since this is a descriptive study, the potential for some biased information, since the data originated from secondary sources.

\section{口EFERENCES}

1. World Health Organization (CH). Global Tuberculosis Report 2018. Geneva: WHO; 2018 [cited 2019 Jan 10]. Available from: https://apps.who.int/iris/ bitstream/handle/10665/274453/9789241565646-eng.pdf

2. Silva-Sobrinho RA, Ponce MAZ, Andrade RLP, Beraldo AA, Pinto ESG, Scatena LM, et al. Effectiveness in the diagnosis of tuberculosis in Foz do Iguaçu, the triple-border area of Brazil, Paraguay and Argentina. Rev Esc Enferm USP. 2013;47(6):1373-80. doi: https://doi.org/10.1590/50080623420130000600018

3. Vasconcellos FC, Chatkin MN. Perfil epidemiológico da tuberculose em Pelotas, Rio Grande do Sul - Brasil. Rev Bras Ciênc Saúde. 2008 [cited 2019 Feb 10];12(3):229-38. Available from: http://periodicos.ufpb.br/index.php/rbcs/ article/view/4467/3374

4. Braga JU; Herrero MB; Cuellar CM. Transmissão da tuberculose na tríplice fronteira entre Brasil, Paraguai e Argentina. Cad Saude Publica. 2011;27(7):1271-80. doi: https://doi.org/10.1590/S0102-311X2011000700003

5. Barrosso SP, Zilly A, Monroe AA, Villa TCS, Silva-Sobrinho RA. Epidemiologia da tuberculose: incidência e mortalidade em Foz do lguaçu - Paraná, 2004 a 2006. In: Silva-Sobrinho RA, Villa TCS, organizadores. Saúde na Fronteira: estudo epidemiológico e operacional da tuberculose. 1 ed. Curitiba: CRV; 2015. p. 2734.

6. Lemos LA, Fiuza MLT, Reis RK, Ferrer AC, Gir Elucir, Galvão MTG. Adherence to antiretrovirals in people coinfected with the human immunodeficiency virus and tuberculosis. Rev Latino-Am Enfermagem. 2016;24:e2691. doi: https://doi. org/10.1590/1518-8345.0537.2691

7. Implantação do plano nacional pelo fim da tuberculose como problema de saúde pública no Brasil: primeiros passos rumo ao alcance das metas. Boletim Epidemiol. 2018 [cited 2019 Jun 5];49(11):1-18. Avallable from: http:// portalarquivos2.saude.gov.br/images/pdf/2018/marco/26/2018-009.pdf

8. Belo EM, Orellana JDY, Levino A, Basta PC. Tuberculose nos municííios amazonenses da fronteira Brasil-Colômbia-Peru-Venezuela: situação epidemiológica. Rev Panam Salud Publica. 2013 [cited 2019 Apr 29];34(5):3219. Available from: https://www.scielosp.org/scielo.php?script=sci_arttext\&pi $d=\$ 1020-49892013001100004$

9. Marques M, Ruffino-Netto A, Marques AMC, Andrade SMO, Silva BAK, Pontes ERJC. Magnitude da tuberculose pulmonar na população fronteiriça de Mato Grosso do Sul (Brasil), Paraguai e Bolívia. Cad Saúde Pública. 2014;30(12):263142. doi: https://doi.org/10.1590/0102-311×00191513
10. Caron-Ruffino M, Ruffino-Netto A. Associação entre alcoolismo e tuberculose pulmonar. Rev Saúde Pública. 1979;13(3):183-94. doi: https://doi. org/10.1590/50034-89101979000300003

11. World Health Organization (CH). Global tuberculosis report 2015. Geneva: WHO; 2015 [cited 2019 Jan 10]. Available from: https://apps.who.int/ris/bitstream/ handle/10665/191102/9789241565059_eng.pd??sequence=1

12. Santos ML, Coeli CM, Batista JDAL, Braga MC, Albuquerque MFPM. Factors associated with underreporting of tuberculosis based on data from Sinan Aids and Sinan TB. Rev Bras Epidemiol. 2018;21:e180019. doi: https://doi. org/10.1590/1980-549720180019

13. Pereira SM, Araújo GS, Santos CAST, Oliveira MG, Barreto ML. Association between diabetes and tuberculosis: case-control study. Rev Saúde Pública. 2016;50:82. doi: http://dx.doi.org/10.1590/s1518-8787.2016050006374

14. Abreu RG, Sousa AIA, Oliveira MRF, Sanchez MN. Tuberculosis and diabetes: probabilistic linkage of databases to study the association between both diseases. Epidemiol Serv Saude. 2017;26(2):359-68. doi: https://doi. org/10.5123/s1679-49742017000200013

15. Arcoverde MAM, Berra TZ, Alves LS, Santos DT, Belchior AS, Ramos ACV, et al. How do social-economic differences in urban areas affect tuberculosis mortality in a city in the tri-border region of Brazil, Paraguay and Argentina. BMC Emerg Med. 2018;18:795. doi: https://doi.org/10.1186/s12889-018-5623-2

16. Herrero MB, Ramos S, Arrossi, $S$. Determinants of non-adherence to tuberculosis treatment in Argentina: barriers related to access to treatment. Rev Bras Epidemiol. 2015;18(2):287-98. doi: https://doi.org/10.1590/19805497201500020001

17. Martin D, Goldberg A, Silveira C. Imigração, refúgio e saúde: perspectivas de análise sociocultural. Saúde Soc. 2018;27(1):26-36. doi: https://doi. org/10.1590/s0104-12902018170870

18. Dhavan P, Dias HM, Creswell J, Weil D. An overview of tuberculosis and migration. Int J Tuberc Lung Dis. 2017;21(6):610-23. doi: https://doi.org/10.5588/ ijtld. 16.0917

19. Aikes S. Rizzotto MLF. Integração regional em cidades gêmeas do Paraná, Brasil, no âmbito da saúde. Cad Saúde Pública. 2018;34(8):e00182117. doi: https:// doi.org/10.1590/0102-311 ×00182117

20. Andrade RLP, Scatolin BE, Wysocki AD, Beraldo AA, Monroe AA, Scatena LM, et al. Tuberculosis diagnosis: primary health care or emergency medical services? Rev Saúde Pública. 2013;47(6):1149-58. doi: https://doi.org/10.1590/500348910.2013047004650

Acknowledgements:

Support from the Coordination for the Improvement of Higher Education Personnel (CAPES) — Brazil. Funding code 001.

Received: 04.12.2019

Approved: 07.10.2019
Débora Christina Santos Souza

E-mail: debora.souza88@hotmail.com 